Kalpa Publications in Computing
Volume 13, 2019, Pages 62-69
Proceedings of the 1st International Con-
ference on Geospatial Information Sciences

\title{
Space-Temporal Study in the Protected Natural Area of Xochimilco Lake with Remote Sensing in the Period 1987-2016
}

\author{
Damián Zamora-Rivas ${ }^{1}$ \\ ${ }^{1}$ Facultad de Ingeniería, Universidad Nacional Autónoma de México, Ciudad Universitaria, CDMX, México. \\ damian.zamora.rivas@gmail.com, https://ingenieria.unam.mx
}

\begin{abstract}
.
Conservation Area Ejidos de Xochimilco y San Gregorio Atlapulco, which is located in the south of the Mexico Basin, is considered as World Heritage Site by UNESCO, and a Ramsar Site, that is, it is a Wetland of International Importance. In spite of these international designations, the conservation area has an environmental problem of many years. This article aims to determine the change of vegetation cover and water in the lake area of Xochimilco over a period of 30 years. Remote Sensing facilitates the monitoring of water bodies and vegetation of conservation zones throughout months, even decades. For the period from the year 1987 to year 2016, normalized vegetation indexes $\mathrm{NDVI}=(\mathrm{NIR}-\mathrm{red}) /(\mathrm{NIR}+\mathrm{Red})$ and NDWI$=(\mathrm{NIR}-\mathrm{SWIR}) /(\mathrm{NIR}+\mathrm{SWIR})$; and normalized water index MNDWI $=($ Green-SWIR $) /($ Green+SWIR $)$, were used together to obtain the changes of areas in vegetation and water in annual images captured by the TM and ETM+ sensors of Landsat 5 and Landsat 7 satellites, respectively. Five classes were obtained (water, water with vegetation, dry vegetation, watered vegetation, and other materials, for instance soil and buildings) with a reliability of $89 \%$.
\end{abstract}

\section{Introduction}

This article aims to determine the change of vegetation cover and water in the lake area of Xochimilco over a period of 30 years. This lake is one of the few natural vestiges of the ancient Lake of Texcoco. Xochimilco Lake, as a declared conservation area has the name of Ejidos de Xochimilco y San Gregorio Atlapulco. It is an important natural place just in middle of one of the biggest cities of the world: Mexico City. Its importance has been recognized by national and international organizations. UNESCO declared it as World Heritage Site in 1987, and was named as Ramsar site in 2004, that is, it is a Wetland of International Importance. Despite of this, this site has an environmental problem,

O. S. Siordia, J.L. Silván Cárdenas, A. Molina-Villegas, G. Hernandez, P. Lopez-Ramirez, R. Tapia-McClung, K. González Zuccolotto and M. Chirinos Colunga (eds.), iGISc 2019 (Kalpa Publications in Computing, vol. 13), pp. $62-69$ 
such as eutrophication and poor water quality, of many years. It has been identified by various authors and organisms (Narchi 2007; Otto, 2014; Núñez-Jiménez, 2015; UNAM, 2014). Remote Sensing facilitates the monitoring of water bodies and vegetation of conservation zones throughout months, even decades.

Xochimilco is in the center of Mexico. It is a sub-basin located south of the Mexico Basin, whose extension of $9568 \mathrm{~km} 2$ belongs mainly to the Panuco Hydrological Region (INEGI, 2002), which covers Mexico City and part of the State of Mexico and Tlaxcala. Xochimilco is at an average altitude of 2,240 meters above sea level, and geographically is located at latitude $19^{\circ} 16^{\prime}$ '24" North and longitude $99^{\circ} 04$ ' $41^{\prime}$ " West. The study site has an area of 2,522 ha $(25.22 \mathrm{~km} 2)$, which makes it the biggest region of ecological conservation in Mexico City (see Fig. 1).

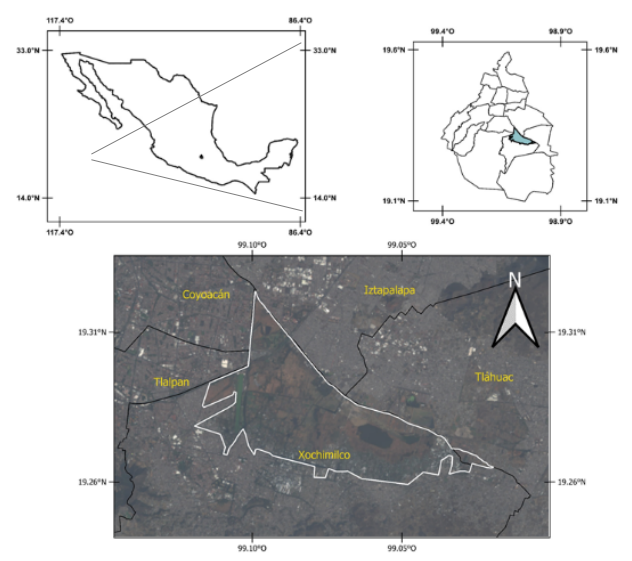

Figure 1: Localization of the study area: Ejidos de Xochimilco y San Gregorio Atlapulco.

\subsection{Vegetation and water bodies identification with Remote Sensing}

There are many ways to identify vegetation with Remote Sensing. One of them is with the division between two spectral ranges, commonly are red (R), that comprise from $0.6 \mu \mathrm{m}$ to $0.7 \mu \mathrm{m}$; and near infrared (NIR), which comprise from $0.7 \mu \mathrm{m}$ to $1.1 \mu \mathrm{m}$. However, since more than forty years exists a normalized ratio called Normalized Difference Vegetation Index, or simply NDVI. It was proposed by Rouse et al. (1973) to be used for ETRS (Earth Resources Technology Satellite), later called Landsat 1. It is defined as:

$$
N D V I=(N I R-R) /(N I R+R)
$$

NDVI, like the rest of the indexes that will be explained below, obtains actual values between -1 and 1 , where positive values indicate presence of vegetation (or water, if it is a water index), and negative values indicate any other material. However, it has been experimentally shown that NDVI has values from 0.2 and on when there is vegetation on the scene (USGS, 2018).

In spite of the benefits of NDVI, it is important to mention that this index is not $100 \%$ certain to identify vegetation (Carlson, 1997). That is why it is recommended to rely on other indexes to complement the information shown by the NDVI. The NDWI (Normalized Difference Water Index), developed by Gao in 1996., is one of these indexes. This one is formulated below:

$$
N D W I=(N I R-S W I R) /(N I R+S W I R)
$$


where NIR is near infrared, while SWIR is the region called shortwave-infrared (1.2-2.5 $\mu \mathrm{m})$. This index allows estimating the amount of water in the vegetation. If it is hydrated, the NDWI index results in positive values.

There are also indexes to study the surface water. Unlike vegetation indexes, it has been several normalized difference water ratios. First one was the NDWI (Normalized Difference Water Index) introduced by McFeeters in 1996 as follows:

$$
N D W I=(\text { Green-NIR }) /(\text { Green }+N I R)
$$

where Green and NIR are the reflectance of green and Near Infrared, respectively. As a side note, this index should not be confused with NDWI by Gao, which is for estimating water content of vegetation. Although both NDWIs have the same terminology, their concepts are completely different.

Just a decade later NDWI (Rogers \& Kearney, 2004), MNDWI (Xu, 2006) and NDPI (Lacaux et al., 2007) were developed.

Due to the number of indexes available, there have been papers that attempt to determine the most suitable index for water, comparing them to each other. Ji et al. (2009) both in the laboratory experimentally and with images of various sensors, concluded that the MNDWI developed by Xu (2006) is the index that shows greater stability in the delimitation of bodies of water through the ETM+ sensor. $\mathrm{Xu}$ index is formulated as follows:

$$
M N D W I=(\text { Green-SWIR }) /(\text { Green }+ \text { SWIR })
$$

where SWIR is shortwave-infrared, while Green is the region from $0.5 \mu \mathrm{m}$ to- $0.6 \mu \mathrm{m}$.

\section{Material and Methods}

Of the 30 years covered in this work, only 27 images of the TM and ETM+ sensors were downloaded from the USGS page (https://earthexplorer.usgs.gov/), which already has geometric correction.

The method used for radiometric correction was the Dark Object Subtraction, proposed by Chavez in 1988, which assumes that, for an ideal situation, there will be a material in the scene with a reflectance equal to zero, but due to the dispersion caused by the atmosphere, the pixels are not completely obscure, reflecting a different brightness value. Thus, for correction, it is enough to subtract from the image histogram the brightness value of the darkest pixel, which represents the dark body.

All images are annual, between November and January of each year.

\subsection{Processing}

The vegetation and water indexes described above were used for each of the annual images. According to the wavelength intervals, the three indexes were calculated with the spectral bands of the TM and $\mathrm{ETM}+$ sensors, rewriting equations (1), (2) and (3) as follows:

$$
\begin{gathered}
N D V I=(B 4-B 3) /(B 4+B 3) \\
N D W I=(B 4-B 5) /(B 4+B 5) \\
M N D W I=(B 2-B 5) /(B 2+B 5)
\end{gathered}
$$

where B2 $(0.52-0.6 \mu \mathrm{m}), \mathrm{B} 3(0.63-0.69 \mu \mathrm{m}), \mathrm{B} 4(0.76-0.9 \mu \mathrm{m})$ and B5 $(1.55-1.75 \mu \mathrm{m})$ are the spectral bands 2, 3, 4 and 5 of TM and ETM+ sensors, respectively. 
Once applied these indexes, three images per year were obtained. Each image has actual values from -1 to 1 but were reclassified to integer numbers. This was according to the Table 1 .

\begin{tabular}{ccc}
\hline Map & Original X value & Assigned X Value \\
\hline \multirow{2}{*}{ NDVI } & $-1<=X<0.2$ & 1 \\
& $0.2<=X<1$ & 2 \\
\hline \multirow{2}{*}{ NDWI } & $-1<=X<0$ & 1 \\
& $0<=X<1$ & 5 \\
\hline \multirow{2}{*}{ MNDWI } & $-1<=X<0$ & 1 \\
& $0<=X<1$ & 7 \\
\hline
\end{tabular}

Table 1: Reclassified values that were assigned to each index

The choice of the ranges shown above was made based on the following. The range of NDVI was selected according to written before about experimental results. Gao (1996) indicates that its NDWI index in general takes positive values for hydrated vegetation. And $\mathrm{Xu}$ (2006) makes clear that its MNDWI index has values from 0 to 1 in the presence of water in the image.

These three reclassified images were multiplied to obtain one image per year, in which it is possible to relate the three indexes according to presence or absence of the material to identified. Then all images were cut to the limits of the Natural Protected Area (see Fig. 1).

With the multiplication, eight values were obtained, as it is shown in the first two columns of table 2 , which represent a possible classification to be obtained. To define the classes, a visual inspection of an aerial photograph with a spatial resolution of one meter, provided by INEGI, was carried out. The aerial photograph was taken in November 2005, same month ETM+ took the image of 2005.

However, certain values were not easy to identify in aerial photography. For instance, the value 14 was presented in less than $0.1 \%$ of the area of each image, making it impossible to classify it. It was decided to give it the class of other materials. Values 7, 35 and 70 appeared in water bodies, so their spectral signatures were plotted (see Fig. 2). Value 5 was dispersed in the images, but with the graph of its spectral signature, which is like urban areas because of its high reflectance in the visible spectrum (see Fig. 3), it was classified as other materials.

\begin{tabular}{cc}
\hline $\begin{array}{c}\text { Multiplication } \\
\text { (NDVI*NDWI*MNDWI) }\end{array}$ & Result \\
\hline $1 * 1 * 1$ & 1 \\
\hline $2 * 1 * 1$ & 2 \\
\hline $1 * 5 * 1$ & 5 \\
\hline $1 * 1 * 7$ & 7 \\
\hline $2 * 5 * 1$ & 10 \\
\hline $2 * 1 * 7$ & 14 \\
\hline $1 * 5 * 7$ & 35 \\
\hline $2 * 5 * 7$ & 70 \\
\hline
\end{tabular}

Table 2: Classes obtained with the multiplication of the normalized indices, and defined classification. 


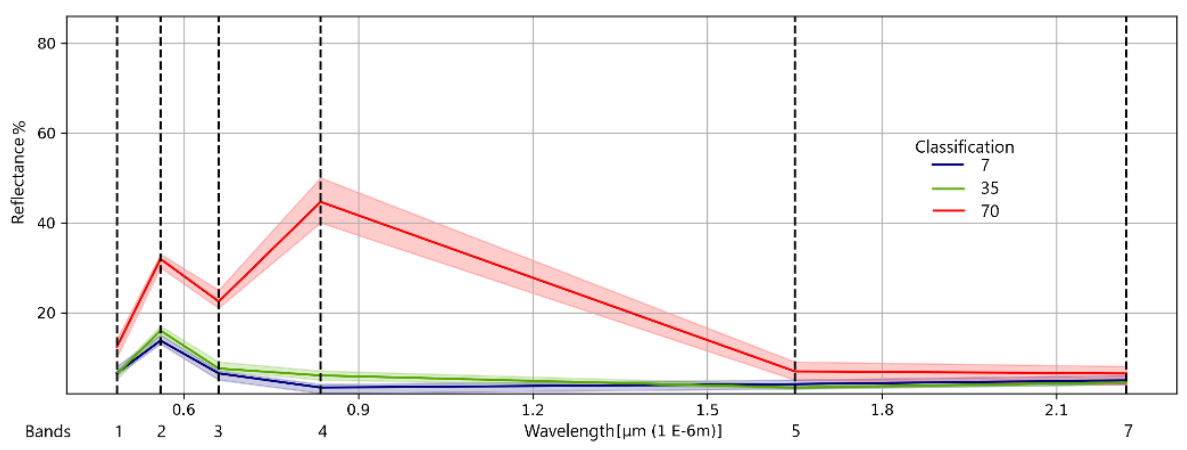

Figure 2: Spectral signatures of the values 7, 35 and 70. All of them are related to presence of water.

Figure 2 shows that classifications 7 and 35 have the same spectral signature, which is typical of water, so they were classified as water. In contrast, the spectral signature of 70 is very similar to the signature of the vegetation, except for the middle infrared (band 5), where a low reflectance can be seen. This suggests water covered with a lot of vegetation, possibly lily. Thus, the value 70 was classified as water with vegetation.

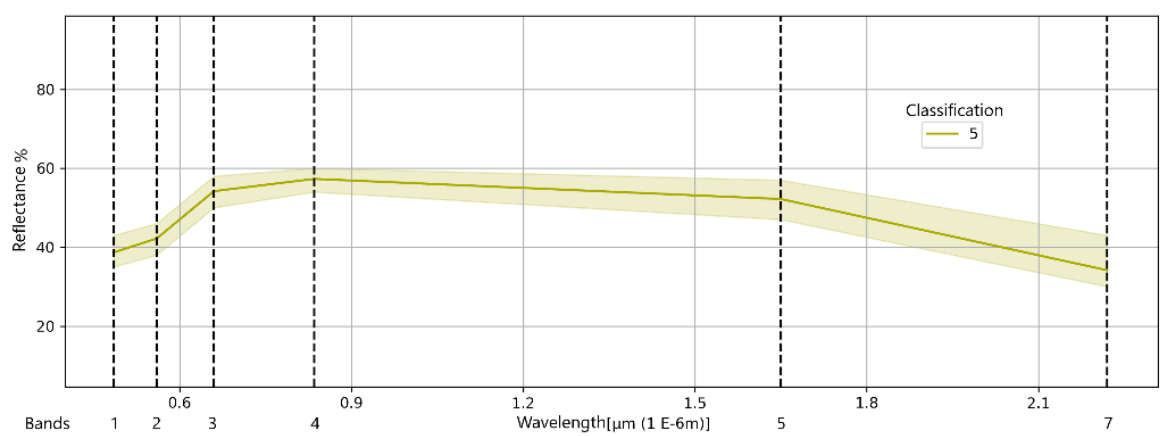

Figure 3: Spectral signature of the value 5, which was classified as other materials.

Once the spectral signatures were plotted, the classes obtained for each year were defined and grouped as it is indicated in the third column of table 3.

It is important to mention that classification "other materials" refers all materials other than vegetation or water, for instance, buildings, human settlements such as greenhouses, soil, among others.

\begin{tabular}{cc}
\hline Values & Class \\
\hline 1,5 and 14 & Other materials \\
\hline 2 & Dry vegetation \\
\hline 10 & Watered vegetation \\
\hline 7 and 35 & Water \\
\hline 70 & Water with vegetation \\
\hline
\end{tabular}

Table 3: Relation between values obtained by the multiplication of indexes, and final classes. 
To estimate the reliability of the classification, an error matrix was made comparing the thematic map with a series of randomly distributed points in aerial photography; according to the recommendations of Francois et al. (2003) (see Fig. 4). The overall reliability was obtained, dividing the sum of the main diagonal values by the sum of all matrix values. It was $89 \%$.

Finally, each classification was limited by polygons, to which the area was calculated, and thus obtain a list of the areas of each year. The total area of the study area is approximately $26 \mathrm{~km}$, however all areas of the identified materials were calculated as percentages, where $100 \%$ is the total area. Thus, the area-time graphs were obtained.

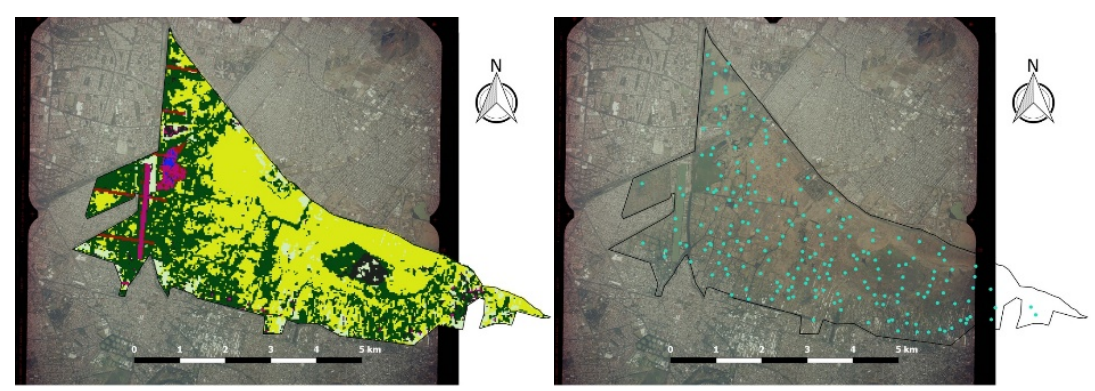

Figure 4: On the left the classified map, and on the right the random points on the aerial photography. These images were compared to make the error matrix.

\section{Results}

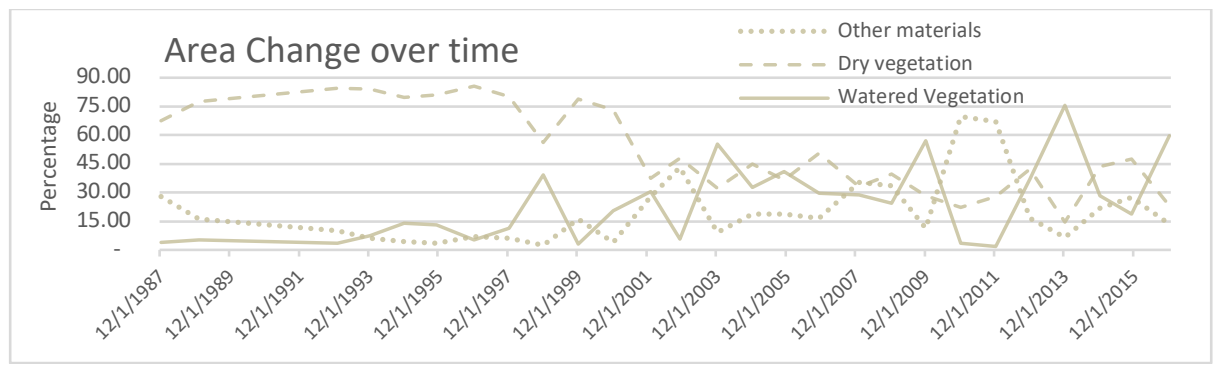

Figure 5: Graph of materials related to vegetation and other materials.

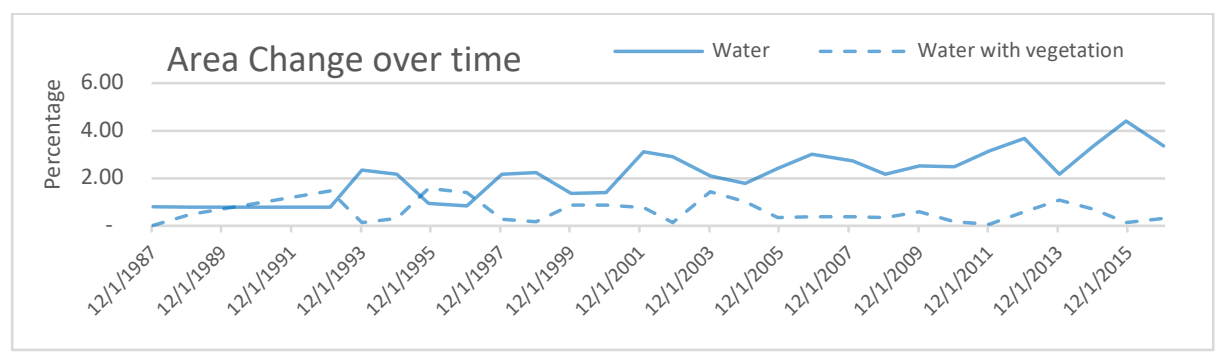

Figure 6: Graph of materials related to water bodies. 
The curves were separated into two graphs because of the difference in the areas. One of them was about water bodies, which cover less than $10 \%$ of the total area; and the other one was about vegetation cover, which cover most of the study area.

Despite being a world heritage site since 1987, it is not until almost a decade after significant changes in vegetation begin to occur. However, vegetation does not show a clear trend. As soon as there is an improvement in water hydration, few years pass for another setback.

In other hand, water have shown have a clear trend in the growth of the area it covers. In addition, there is a constant cover of vegetation in bodies of water. This, as indicated by various authors (Rydings \& Rast, 1989; Gore, 2003), is not always good for the health of the lake ecosystem. It is worth mentioning that the lake area is famous for its channels, which do not have a width of more than 30 meters, resolution of the TM and ETM+ sensors.

\section{Conclusions}

Five classes were determined in the study area: two related to bodies of water (water and water with vegetation), two of vegetation (watered vegetation and watered vegetation), and one associated with materials such as soil and human settlements. The classification has a reliability of $89 \%$

Growth of areas without vegetation and urban settlements is observed, which could be regulated if the monitoring of the area were constant.

Finally, there have been several studies and programs to improve the site, but the information shows that they have not been enough well implemented; and much less they have been followed up.

\section{References}

1. Author, U.: Url title, URL, last accessed $x$ x xGeospatial Contribution Title

2. Carlson, T. N. \& Ripley, D. A. On the relation between NDVI, Fractional Vegetation Cover and Leaf Area Index. Remote Sensing of Environment, $62 \quad$ (3), 241-251 (1997), https://www.sciencedirect.com/science/article/abs/pii/S0034425797001041.

3. Chavez, P. S. Jr. An improved dark-object subtraction technique for atmospheric scattering correction of multispectral data. Remote Sensing of Environment, 24 (3), 459-479, (1998), https://www.sciencedirect.com/science/article/abs/pii/0034425788900193.

4. Francois M., Díaz-Gallegos J. R. y Pérez Vega A. Evaluación de la confiabilidad temática de mapas o de imágenes clasificadas: una revisión. Investigaciones Geográficas, Boletín del Instituto de Geografía, UNAM, 51, 53-72,

(2003), https://www.researchgate.net/publication/262443478_Evaluacion_de_la_confiabilidad_tetemati_de_mapas_ o_de_imagenes_clasificadas_una_revision

5. Gao Bo-Cai. NDWI - A normalized Difference Water index for Remote Sensing of vegetation liquid water from space. Remote Sensing of Environment, 58 (3), 257-266 (1996), https://www.sciencedirect.com/science/article/abs/pii/S0034425796000673.

6. Gore, P. F. W. (2003) Lake Formation. In Dasch E. J. (Ed.), Water Science and Issues. 247-250. USA: Macmillan Reference USA.

7. INEGI, http://www.inegi.org.mx, last accessed 5-12-2016, Estadística del Medio Ambiente del Distrito Federal y Zona Metropolitana 2002

8. Ji, L., Zhang, L. \& Wylie, B. Analysis of dynamic thresholds for the Normalized Difference Water Index. Photogrammetric Engineering \& Remote Sensing, $75 \quad$ (11), 1307-1317 (2009), https://www.researchgate.net/publication/275681435_Analysis_of_Dynamic_Thresholds_ffo_the_Normaliz ed_Difference_Water_Index. 
9. Narchi, N. E., Deterioro ambiental en Xochimilco. Lecciones para el cambio climático global. Veredas 27 (Cambio climático y desarrollo sustentable), 177-197, (2013), https://www.researchgate.net/publication/235699826_Deterioro_Ambiental_en_XochimilcX_Lecciones_par a_el_cambio_climatico_global

10. Núñez-Jiménez, M., Cuestas-Alvarado, P. R. y Almada-Ávila, G., Producción primaria como indicadora de eutrofización de los canales del lago de Xochimilco (México). E-Bios 2 (9), 20-30, (2015), http://cbs1.xoc.uam.mx/e_bios/docs/2016/31.pdf

11. Otto, E. S. El rescate Ecológico de Xochimilco: Las Culturas del Agua. E-Bios Manejo Integral de la Cuenca de Xochimilco $\quad$ y $\quad$ sus http://cbs1.xoc.uam.mx/e_bios/docs/2014/Manejo_Integral_Cuenca_Xochimilco.pdf

12. Rouse Jr., J. W., Haas, R. H., Schell, J. A. \& Deering, D. W. (1973). Monitoring vegetation systems in the Great Plains with ERTS. S. C. Freden, E. P. Mercanti, \& M. Becker (Eds.), Third Earth Resources Technology Satellite-1 Symposium. Technical presentations, section A, vol. I (pp. 309 - 317). Washington, DC: National Aeronautics and Space Administration (NASA SP-351).

13. Ryding S.-O. \& Rast W. The Control of Eutrophication of Lakes and Reservoirs. Volume I UNESCO, París (1989)

14. UNAM Análisis del estado de conservación ecológica del sistema lacustre chinampero de la superficie reconocida por la UNESCO como Sitio Patrimonio de la Humanidad en Xochimilco, Tláhuac y Milpa Alta. Informe Final https://www.azp.cdmx.gob.mx/storage/app/uploads/public/58b/6f8/f0e/58b6f8f0e0810036081003.pdf

15. USGS https://phenology.cr.usgs.gov/ last accessed 27-06-2018. NDVI, the Foundation for Remote Sensing Phenology.

16. $\mathrm{Xu}, \mathrm{H}$. Modification of normalized difference water index (NDWI) to enhance open water features in remotely sensed imagery. International Journal of Remote Sensing, 27, 3025-3033, (2006), https://www.researchgate.net/publication/232724072_Modification_of_Normalized_Difference_Water_Inde x_NDWI_to_Enhance_Open_Water_Features_in_Remotely_Sensed_Imagery. 